\title{
THE RELATIONSHIP BETWEEN EMPLOYEE MOTIVATION, JOB SATISFACTION AND CORPORATE CULTURE
}

\author{
WANDA ROOS \\ RENÉ VAN EEDEN \\ Department of Psychology \\ University of South Africa \\ South Africa \\ Correspondence to: René van Eeden \\ e-mail: veeder@unisa.ac.za
}

\begin{abstract}
In this study, relationships between employee motivation, job satisfaction and corporate culture were hypothesised and investigated. The sample that was investigated consisted of the majority of the permanent-staff complement of a marketing research company in South Africa. Three instruments were used to measure the constructs concerned, namely the Motivation Questionnaire (MQ), the Experience of Work and Life Circumstances Questionnaire (WLO) and the Corporate Culture Questionnaire (CCQ). Pearson product-moment coefficients were then calculated and the linear relationships were further explored through canonical-correlation analysis. A possible moderator effect of employee motivation was also explored. The findings provided support for the linear relationships and, more importantly, identified the drivers of these relationships. The findings did not support the moderator effect. Using these findings, marketing research organisations, in particular, can be guided in terms of workplace attitudes under managerial influence.
\end{abstract}

Keywords: Corporate culture, job satisfaction, marketing research

Against the background of increasing local and global competitiveness, it is crucial for any organisation, particularly for those in developing countries with limited skills resources, such as South Africa, to ensure that it consistently develops and retains a loyal, committed and able workforce. This presupposes employees who are satisfied with the work that they do and with the culture of the organisation that they are employed by and who are consequently motivated to continue their relationship with that organisation.

Peters and Waterman (1982) regard the commitment of employees to organisational values and beliefs - the organisational culture - as a crucial factor in the success of a company. The way that people are managed has a powerful impact both on productivity and on profitability. Variance of these aspects can be accounted for by differences in corporate culture, together with different levels of job satisfaction and employee motivation and commitment (Finck, Timmers \& Mennes, 1998; Schofield, 1998; Watson, 1994). Organisational effectiveness depends on how organisations manage their employees (Moynihan \& Pandey, 2007).

This study regarded motivation and job satisfaction as key determinants of organisational success, both of which are influenced by aspects of corporate culture. Research on these three concepts and on combinations of these concepts has been reported but this investigation contributes to this body of knowledge by considering all three concepts in the same study.

A thorough understanding of the nature and significant sources of motivation and job satisfaction, insofar as these concepts are related to corporate culture, can enable employers to effect the required positive strategic changes towards optimal employee loyalty and retention. For example, an organisation can select candidates with a high degree of potential fit with the organisation's culture or adapt certain of its human-resources policies and practices where these have been shown to hamper employee motivation and satisfaction.
This study was conducted in a marketing research type of organisation. With regard to employee motivation and job satisfaction, the typical South African marketing research environment poses several significant challenges to employers. It is, by nature, a fast-paced and highly pressured environment due to a high degree of intricate process interdependence between work teams, stringent deadlines, high work volumes and long working hours (Bard \& Moore, 2000). In addition, marketing research analysts are also required to demonstrate a combination of analytical, writing and people skills on top of a propensity for both a detailed and a conceptual approach to their work (Deetlefs, personal communication, 2003). Furthermore, the marketing research arena is not generally associated with highly lucrative employment-benefit packages. All of these factors add to the difficulty that employers in the South African marketing research industry have in recruiting suitable employees, developing them to levels where they make a significant contribution to the profitability of the organisation and ultimately retaining them as intellectual and business capital over the long term.

Apart from the potential impact on an organisation, the loyalty and retention of professional, well-trained and optimally productive personnel also have economic implications on both a national and, increasingly, an international level. Nationally, marketing research in South Africa is a fast-growing and highly competitive industry on which several other industries rely for both their short-term and their long-term strategic and operational directives. Internationally, more and more South African marketing research companies are being commissioned to conduct major studies by or in association with international organisations.

Despite the focus on the marketing research field, it is believed that the findings of this study will be relevant to most other industries where organisational performance is dependent largely on performance delivery by staff. Despite their individual differences, the motivation theories show that, by and large, people at work - wherever that may be - are motivated and satisfied by many of the same or similar key characteristics of the workplace. 


\section{THEORETICAL BACKGROUND ON EMPLOYEE MOTIVATION, JOB SATISFACTION AND CORPORATE CULTURE}

The term "motivation" is derived from the Latin term movere, which means "to move" (Baron, Henley, McGibbon \& McCarthy, 2002). A great many definitions of the motivation construct have been postulated over the several decades during which this multifaceted concept has been researched. Campbell and Pritchard (1976, p.78) define motivation as "a label for the determinants of the choice to initiate effort on a certain task, the choice to expend a certain amount of effort, and the choice to persist in expending effort over a period of time." Schultz and Schultz (1998) regard motivation as simply the personal and workplace characteristics that explain why people behave the way that they do on the job. Work characteristics in this regard refer to specific characteristics of a person's job, such as its task variety, whereas personal characteristics include those determined by a person's personality, such as an intrinsic need for achievement. Emphasis on either intrinsic motivation (by, for example, Gouws, 1995) or goal or reward-driven behaviour (by, for example, Beach, 1980) has also been noted. Du Toit (1990) distinguishes between individual characteristics, such as people's interests, values and needs, work characteristics, such as task variety and responsibility, and organisational characteristics, such as the policies, procedures and customs of an organisation. Depending on the particular approach adopted, motivation theories are generally classified into three categories, namely needs-based, cognitive and drive-andreinforcement theories (Baron et al., 2002).

The importance of job satisfaction is underscored by its positive and reciprocal relationship with life satisfaction (Judge \& Watanabe, 1993) and its impact on personal, social and work life (Sempane, Rieger \& Roodt, 2002). Arnold and Feldman (1986, p. 86) describe job satisfaction as "the amount of overall affect that individuals have toward their job." McCormick and Ilgen (1980) also regard job satisfaction as a person's attitude towards his or her job, which may vary along a continuum from positive to negative. Beck (1983) adds that, since a job has many characteristics, job satisfaction is necessarily a summation of worker attitudes regarding all these. An individual typically experiences different levels of satisfaction across different job aspects (Spector, 2003). According to Schultz and Schultz (1998), job satisfaction encompasses both the positive and the negative feelings and attitudes that people hold about their jobs, these depending on many work-related and personal characteristics. Walker (1980) proposes a model in which the determinants of performance, job satisfaction and motivation are indicated as work-related variables (the work context, task activities or content and job objectives), the individual (individual skills, abilities and knowledge) and rewards. This model includes aspects such as organisational functioning, task and job characteristics, physical working conditions, career matters, social and relationship matters, and remuneration packages and personnel policies. Theories on job satisfaction involve motivational, emotional and informational components (Beck, 1983) and, as such, overlap with theories on motivation. Examples include comparison-process theory (Walker, 1980), instrumentality theory, which corresponds with Vroom's (1964) motivational theory, social influence theory (Van Vuuren, 1990), equity theory (Adams, 1965) and two-factor theory, with its reference to dissatisfiers, which relates to job satisfaction and motivation (Gouws, 1995).

Much controversy exists regarding the general nature of corporate culture as a construct (Cooper, Cartwright \& Earley, 2001) and, as a result, several different definitions of the concept have been formulated, each from the unique perspective of its author. Schein (1985, p. 86) offers a comprehensive definition and describes corporate culture as "a pattern of shared basic assumptions, invented, discovered or developed by a given group, as it learns to cope with its problems of external adaptation and internal integration, that has worked well enough to be considered valid, and therefore, is to be taught to new members of the group as the correct way to perceive, think and feel in relation to those problems." Alvesson (2002) supports this view by stating that a set of common, taken-for-granted ideas, beliefs and meanings among employees is necessary for continued organised activity, as this obviates the need for the continual interpretation and reinterpretation of meanings. The view of corporate culture most often encountered incorporates the idea of shared values, beliefs and norms (Weeks \& Lessing, 1988) that impact not only on the behaviour of employees at work but also on the way that employees think and feel about a company (Schein, 1984). Corporate culture is difficult to change and exerts considerable influence on the motivation and satisfaction levels of employees insofar as these relate to the work environment. Ott (1989) elaborates on several dominant perspectives of organisation theory in a comprehensive historical overview of the development of the corporate culture perspective. This overview shows a repetitive fluctuation between a more rational, goal-orientated and mechanistic approach versus a more qualitative focus on human behaviour and the acknowledgment of the impact of values, beliefs and preferences on organisational behaviour.

The feelings and attitudes of employees towards their work are influenced significantly by their sources both of motivation and of demotivation (Spector, 2003). In addition, the manner in which they perceive the culture of their organisation has a direct bearing on both their level of motivation and the degree of job satisfaction that they experience. The preceding discussion shows that several related personal, job and organisational aspects have a similar impact on motivation and satisfaction. If either employee motivation or job satisfaction is to be affected, one or more of these personal, job-related or organisational variables should be changed (Perry \& Porter, 1982). The corporate culture construct is represented collectively by the set of organisational characteristics influencing employee motivation and job satisfaction, since these portray the underlying values, beliefs and assumptions of an organisation.

\section{THE RELATIONSHIP AMONG MOTIVATION, JOB SATISFACTION AND CORPORATE CULTURE}

Employee motivation is an innate force shaped and maintained by a set of highly individualistic factors that may change from time to time, depending on the particular needs and motives of an employee. Environmental factors do not have a causal link with motivation but do impact on the level of motivation experienced by an employee and, together, innate and environmental forces determine behaviour at work (Pinder, 1998). Gouws (1995) points out that the factors that motivate employees are the same ones that contribute towards their satisfaction in the workplace and subsequently concludes that motivated employees are generally also satisfied with their work. Motivation therefore manifests in job satisfaction (attitudinal) and performance (behavioural) and thus provides the link between employee job satisfaction and employee performance.

In this study, the relationships between specific motivational characteristics (characteristics that are both personal and jobrelated) and job satisfaction are discussed first. This is followed by a discussion on the relationships between organisational characteristics and job satisfaction. Finally, an inferred relationship between organisational characteristics and employee motivation is discussed.

\section{The relationship between employee motivation and job} satisfaction

Certain needs and motives experienced by employees are indicative of their energy and dynamism while at work, such as their need for achievement and power, their level of activity under pressure and the extent to which they are motivated by a 
competitive environment. A number of studies (Du Plessis, 2003; Maslow, 1968; Rothmann \& Coetzer, 2002; Stinson \& Johnson, 1977) have shown that the extent to which people are motivated by challenging tasks and by the sense that their abilities are being stretched directly impacts on the job satisfaction that they experience. People are motivated by their objectives and goals (Spector, 2003); goal involvement and goal attainment have also been shown to be positively related to job satisfaction (Bellenger, Wilcox \& Ingram, 1984; Coster, 1992; Strydom \& Meyer, 2002). These results are explained by the contribution that achievement makes towards a person's self-esteem (Beach 1980), which reinforces his or her sense of contributing towards an organisation. A need for achievement is often linked to a need for power in the workplace (McClelland, 1987) and it has been shown that power is a significant predictor of job satisfaction for those workers who are motivated by it (Becherer, Morgan \& Richard, 1982; Coster, 1992; Hoole \& Vermeulen, 2003).

Another dimension of work motivation relates to the synergy that people experience between their motivational drive system and the characteristics of their work environment. This includes the extent to which they are motivated by opportunities for interaction at work, by praise and tangible recognition, by the synergy between their own and the organisation's values and principles, by their need for job security and by their need for opportunities for continual growth and development. The need for security is one of the most basic needs. Job security refers specifically to one's expectations about continuity in a job situation and extends to concern over loss of desirable job features, such as promotion opportunities and working conditions (Davy, Kinicki \& Scheck, 1997). This variable has been shown to be an important predictor of job satisfaction (CohenRosenthal \& Cairnes, 1991; Davy et al., 1997; Hoole \& Vermeulen, 2003; Moon, 2000; Ritter \& Anker, 2002; Visser, Breed \& Van Breda, 1997). Studies have also shown that many employees experience job satisfaction because their affiliation needs are being satisfied to some extent at work (Cohen-Rosenthal \& Cairnes, 1991; Hoole \& Vermeulen, 2003; Strydom \& Meyer, 2002; Van Vuuren, 1990; Visser et al., 1997). Needs related to the self and higher-order needs that affect job satisfaction include the recognition of performance (Beach, 1980; Bellenger et al., 1984; Guppy \& Rick, 1996; Van Vuuren, 1990), an environment that corresponds with personal values (Deshpande, 1996; Hoole \& Vermeulen, 2003; Viswesvaran \& Deshpande, 1996) and opportunities for training and development that satisfy the need for self-actualisation (Coster, 1992).

The intrinsic motivation dimension refers to an increase in motivation corresponding with meaningful and stimulating work, flexible structures and procedures, and an adequate level of autonomy. Literature shows a positive relationship between job satisfaction and the need to perform jobs that are challenging and that provide variety, interest and stimulation (Becherer $e t$ al., 1982; Coster, 1992; Fried \& Ferris, 1987; Jernigan, Beggs \& Kohut, 2002; Kemp, Wall, Clegg \& Cordery, 1983; Moynihan \& Pandey, 2007; Strydom \& Meyer, 2002; Vercueil, 1970; Visser et al., 1997). Literature also shows that repetitive jobs lead to lower levels of job satisfaction (Shepard, 1973; Stinson \& Johnson, 1977). Autonomous activity is an innate need experienced by many people (Beach, 1980; Coster, 1992; Vercueil, 1970) and scope for greater self-regulation in a work context leads to greater job satisfaction (Agho, Mueller \& Price, 1993; Becherer et al., 1982; Coster, 1992; Fried \& Ferris, 1987; Guppy \& Rick, 1996; Jernigan et al., 2002; Orpen, 1994; Stinson \& Johnson, 1977; Tyagi, 1985; Weaver, 1988). An employee's perceived control over his or her own work was also found to moderate the relationship between levels of motivation and job satisfaction experienced (Orpen, 1994).

The extrinsic motivation dimension is represented by aspects such as the need for financial reward, positive promotion prospects, and position and status. Extrinsic rewards provided by an organisation are those that are tangible and visible to others. A significant positive correlation has been found between the extent to which people are motivated by financial reward and their level of satisfaction with the work (Agho et al., 1993; Bellenger et al., 1984; Hoole \& Vermeulen, 2003; Mol, 1990; Strydom \& Meyer, 2002; Thomson, 2003; Visser et al. 1997). Praise and recognition seem to be valued more by senior employees (Bellenger et al., 1984). This represents the affirmation of an individual's self-worth, which is also represented by the positive relationship between position and status as motivators and the experience of job satisfaction (Hoole \& Vermeulen, 2003; Jernigan et al., 2002). Many employees, especially highly achievement-orientated people, are strongly motivated by opportunities for promotion. This has been shown to improve job satisfaction significantly (Coster, 1992; Hoole \& Vermeulen, 2003; Moynihan \& Pandey, 2007; Visser et al., 1997).

From the aforegoing, it is clear that the realisation of personal and job-related characteristics that motivate an individual is related to increased job satisfaction. It was therefore hypothesised that the different dimensions of motivation representing these characteristics are positively related to job satisfaction.

\section{The relationship between corporate culture and job} satisfaction

Some support for a relationship between job satisfaction and certain dimensions of corporate culture has been found. These dimensions represent organisational aspects that impact on job satisfaction, alongside the personal and job-related aspects that were discussed in the previous section.

The performance dimension includes an organisation's concern for the amount and quality of work that is done, its encouragement of creativity, and its customer and commercial orientation. Numerous studies have shown that an unrealistic workload has a decreasing effect on job satisfaction (Agho et al., 1993; Becherer et al., 1982; Bhargava \& Kelkar, 2000). Concern for quality in work output and the safety and security of staff and clients (Cohen-Rosenthal \& Cairnes, 1991; Moynihan \& Pandey, 2007; Putti \& Kheun, 1986) as well as a culture of innovation and creativity (Coster, 1992; Johnson \& McIntye, 1998; Odom, Boxx \& Dunn, 1990) enhance job satisfaction. The last-mentioned has also been linked to employee commitment to the organisation.

The human-resources dimension is reflected by an organisation's policies regarding the value and treatment of employees. Concern for employees is displayed through a supportive attitude in a people-orientated, encouraging and trusting environment. Such employer attitudes are positively related to job satisfaction (Agho et al., 1993; Putti \& Kheun, 1986; Ritter \& Anker, 2002) and to employee commitment and group cohesion (Odom et al., 1990; Van Vuuren, 1990). Another value related to job satisfaction is that of non-discrimination as reflected in fairness and equal opportunities for all workers (Coetzee \& Vermeulen, 2003; Ritter \& Anker, 2002; Veeran \& Katz, 2002; Visser et al., 1997).

The decision-making culture of an organisation is reflected by the degree of formalisation that it subscribes to, with a bureaucratic and highly structured approach being negatively related to satisfaction and commitment (Du Preez, 2003; Goodman, Zammuto \& Gifford, 2001; Lok \& Crawford, 2001; Odom et al., 1990). However, Strydom and Meyer (2002) have found that the influence of such working conditions depends on the preference of particular employees. The hierarchical decision-making style characterising a regulated system seems to be part of the problem (McNeely, 1983; Visser et al., 1997). A participating style enhances job satisfaction, specifically participation in setting standards (Churchill, Ford \& Walker, 1976; Elizur, 1990), management involving staff in decisionmaking (Du Preez, 2003; Maree, 2000), employees having some degree of influence over their jobs (Gunter \& Furnham, 1996) and employees assisting in problem-solving (Cohen-Rosenthal \& Cairnes, 1991). 
Several authors (Cohen-Rosenthal \& Cairnes, 1991; Du Preez, 2003; Gunter \& Furnham, 1996; McNeely, 1983; Moynihan \& Pandey, 2007; Ritter \& Anker, 2002; Strydom \& Meyer, 2002; Visser et al., 1997) have concluded that job satisfaction is facilitated significantly by an organisational culture characterised by positive lateral and vertical relationships among staff, and by effective and efficient interpersonal communication. Having positive interpersonal relationships with people at work contributes to a supportive environment.

Overall, literature supports the views of Putti and Kheun (1986) and Sempane et al. (2002) that corporate culture impacts on job satisfaction. It was therefore hypothesised that the different dimensions of corporate culture are positively related to job satisfaction.

\section{The relationship between corporate culture and employee motivation}

Parallels can be drawn between the variables that link motivation and job satisfaction and those that link corporate culture and job satisfaction. For example, a need for achievement and an organisation's performance culture are both positively related to job satisfaction. Literature furthermore shows that the relationship between job satisfaction and corporate culture is strengthened by synergy between individual motives and needs, and organisational culture. For example, the positive relationship between job satisfaction and a culture of innovation and creativity is more prominent for those motivated by opportunities for creativity (Coster, 1992; Johnson \& McIntye, 1998; Odom et al., 1990). Furthermore, the influence of aspects of the decision-making culture on job satisfaction depends on synergy between employee preference and the degree of formalisation (Strydom \& Meyer, 2002). Finally, the relationship between a supportive environment and job satisfaction is underlined by the need for such support, which many people have, especially at work (Cohen-Rosenthal \& Cairnes, 1991; Du Preez, 2003; Gunter \& Furnham, 1996; McNeely, 1983; Ritter \& Anker, 2002; Strydom \& Meyer, 2002; Visser et al., 1997). A third hypothesis was consequently formulated, namely that the different dimensions of corporate culture are also positively related to the dimensions of motivation.

\section{A three-way relationship among corporate culture, employee motivation and job satisfaction}

In line with previous research involving attitudes (De Cuyper \& De Witte, 2005; Visser \& Coetzee, 2005), the possibility of a more complex relationship has to be considered. Literature that implies a relationship between corporate culture and employee motivation (based on the relationships of these constructs with job satisfaction) also seems to point to a stronger relationship between corporate culture and satisfaction when the former is related to relevant aspects of motivation. A fourth hypothesis was therefore formulated, namely that employee motivation serves as a moderator variable in the relationship between corporate culture and job satisfaction.

\section{RESEARCH DESIGN}

\section{Participants}

The sample was one of convenience: it consisted of $87 \%$ $(N=118)$ of the permanent-staff complement of a prominent marketing research company with several branches in South Africa. Participation was voluntary. A letter from the managing director did encourage participation, however; it also ensured confidentiality. Ultimately, all functional units in the company as well as all levels of staff participated in the study.

The marketing research process follows a universal routine, and organisational structures and procedures are set up to optimise this process. Due to the similar nature of the work of marketing research companies, it was expected that most marketing research companies apply similar structural and procedural operations. It was therefore assumed that the sample on which this study was based would be largely representative of the marketing research industry in South Africa.

The sample, stratified according to age, gender, job tenure, educational level and seniority, is presented in Table 1. Most employees were between 20 and 30 years old. There was an almost equal distribution of men and women. There was a fairly equal distribution of employees among the various categories of tenure, except for those who had more than 10 years of service, who were in the minority. The largest group of employees had a college or technikon qualification, while smaller groups of similar size had a high-school qualification, and Bachelors and postgraduate degrees. Senior and middle management represented $8 \%$ and $23 \%$ of the staff complement respectively, with the general staff making up the rest.

\section{Measuring instruments}

Three instruments were used to measure the constructs concerned. These are the Motivation Questionnaire (MQ), which was used to measure the dimensions of employee motivation, the Experience of Work and Life Circumstances Questionnaire (WLQ), which was used to assess the job satisfaction of the respondents, and the Corporate Culture Lite Questionnaire (CCQ Lite), which provided an assessment of the perceived culture of the organisation.

\section{Motivation Questionnaire (MQ)}

The Motivation Questionnaire (MQ) consists of 8 items in each of 18 scales, totalling 144 short, job-related items completed on custom-designed, computer-read answer sheets. A Likert-scale format is used and raw scores are transformed to stens using a norm group extracted from the general British population. Four dimensions of employee motivation, each consisting of a number of scales, are measured, namely Energy and dynamism, Synergy, Intrinsic motivation and Extrinsic motivation. These dimensions are based on factor analyses carried out by the test developer. Cronbach alpha coefficients of between 0,47 and 0,83 for the scales are reported in the manual, which also contains support for the criterion-related and construct validity of the questionnaire (Baron et al., 2002). Factor analyses support the second-order dimensions.

In this study, Cronbach alpha coefficients ranged from 0,54 to 0,85 across the various scales. These coefficients were similar to those determined for the standardisation sample and, with the exception of three of the scales, could be regarded as "acceptable" to "high", especially if one considers that the results of this study are interpreted at a group level (Huysamen, 1996). Furthermore, the study used the scores on the dimensions in the analyses. The reliabilities for these were: Energy and dynamism $=0,91$; Synergy $=0,85$; Intrinsic motivation $=0,73$; and Extrinsic motivation $=0,85$. Intercorrelations between the scales in each dimension provided support for the four dimensions.

\section{Experience of Work and Life Circumstances Questionnaire (WLQ)}

The Experience of Work and Life Circumstances Questionnaire (WLQ) is based on the rationale that an employee with a high level of stress experiences problems arising from the environment, which can lead to a reduced level of job satisfaction in the case of stress emanating from work-related issues. The questionnaire consists of two parts, namely "experience of work" and "circumstances and expectations".

Only the second part was relevant to this study. The "circumstances" section consists of 23 items, of which the 7 related to circumstances that can cause stress within the work situation were used. The "expectations" section consists of 53 items (categorised in terms of 6 scales) dealing with the extent 
to which expectations in the work situation are perceived to be fulfilled. A five-point scale is used. A South African sample (Grade 10 level) was used to categorise the total score on each scale as "very high", "high" and "normal". Kuder Richardson-8 coefficients ranging from 0,83 to 0,86 for the different fields are reported in the manual together with support for the construct validity of the questionnaire (Van Zyl \& Van der Walt, 1991). Cronbach alpha coefficients ranging from 0,74 to 0,88 and an overall value of 0,87 were found in this study.

\section{Corporate Culture Lite Questionnaire (CCQ Lite)}

This study utilised a shortened version of the Corporate Culture Questionnaire (CCQ), namely the Corporate Culture Lite Questionnaire (CCQ Lite). This consists of 69 items answered on a 5-point scale. The items are categorised into four domains (Performance, Human resources, Decision making and Relationships), each consisting of five to seven 3-item scales. Alpha coefficients for the CCQ range from 0,72 to 0,89 . Reliability and validity data for the CCQ Lite were being collected at the time of this study, although positive results in this regard seemed likely (Davies, Phil \& Warr, 2000). An intercorrelation analysis across all scales confirmed that the domains identified for the CCQ were also applicable to the CCQ Lite.

In this study, Cronbach alpha values ranging from 0,45 to 0,85 were found for the different scales. With the exception of 6 of the 23 scales, these coefficients were acceptable (Huysamen, 1996) and the reliabilities for the combinations of scales in terms of domains (used in analyses in this study) were higher: Performance $=0,77$; Human resources $=0,88$; Decision making $=0,74$; and Relationships $=0,87$. Intercorrelations between the scales within each domain supported the combination of scales but, at the same time, also reflected the lower communalities associated with the low reliabilities found for some of the scales in two of the domains, namely Performance and Decision making.

\section{Procedure}

During meetings with senior staff of the human resources division of the company, it was decided to invite and encourage all permanent staff employed by the organisation for at least six months to partake in the study. A letter from the managing

TABLE

Sample structure

\begin{tabular}{lr}
\hline AGE DISTRIBUTION & N \\
\hline 20 to 30 years & 69 \\
31 to 40 years & 35 \\
41 or older & 14 \\
GENDER DISTRIBUTION & \\
\hline Male & 55 \\
Female & 63 \\
JOB TENURE DISTRIBUTION & \\
\hline Less than 1 year & 29 \\
1 to 2 years & 20 \\
3 to 5 years & 36 \\
6 to 10 years & 22 \\
More than 10 years & 10 \\
missing & 1 \\
EDUCATION LEVEL DISTRIBUTION & \\
\hline High School & 24 \\
College/Technikon & 43 \\
University: Bachelors Degree & 21 \\
University: Postgraduate degree & 28 \\
missing & 2 \\
SENIORITY DISTRIBUTION & 27 \\
\hline Senior management & 82 \\
Middle management & \\
Staff &
\end{tabular}

TABLE 2

Pearson correlations between the dimensions of the MQ and the scales of the WLQ

\begin{tabular}{|c|c|c|c|c|}
\hline & $\begin{array}{l}\text { ENERGY } \\
\text { AND } \\
\text { DYNAMISM }\end{array}$ & SYNERGY & INTRINSIC & EXTRINSIC \\
\hline \multicolumn{5}{|c|}{ Organisational functioning } \\
\hline correlation & 0,390 & $-0,040$ & $-0,080$ & 0,020 \\
\hline$p$-value & 0,000 & 0,632 & 0,396 & 0,871 \\
\hline \multicolumn{5}{|c|}{ Task characteristics } \\
\hline correlation & 0,460 & 0,080 & 0,050 & 0,110 \\
\hline$p$-value & 0,000 & 0,377 & 0,604 & 0,234 \\
\hline \multicolumn{5}{|c|}{ Physical working conditions } \\
\hline correlation & 0,270 & 0,060 & $-0,010$ & 0,040 \\
\hline$p$-value & 0,003 & 0,502 & 0,925 & 0,695 \\
\hline \multicolumn{5}{|c|}{ Career matters } \\
\hline correlation & 0,270 & $-0,030$ & $-0,050$ & $-0,020$ \\
\hline$p$-value & 0,003 & 0,737 & 0,568 & 0,818 \\
\hline \multicolumn{5}{|c|}{ Social matters } \\
\hline correlation & 0,350 & 0,130 & 0,120 & 0,150 \\
\hline$p$-value & 0,000 & 0,148 & 0,178 & 0,110 \\
\hline \multicolumn{5}{|c|}{ Remuneration, benefits, policy } \\
\hline correlation & 0,410 & $-0,140$ & $-0,070$ & $-0,210$ \\
\hline$p$-value & 0,000 & 0,117 & 0,448 & 0,022 \\
\hline
\end{tabular}

director to all the selected members of staff requesting their open and honest participation and assuring them of the confidentiality of their responses launched the project. It was also decided that the company name would be kept confidential.

Data collection took place over a period of seven weeks. The researcher (in the case of one session, a consultant) administered the measuring instruments during a number of sessions that lasted between 50 and 90 minutes to which up to 20 employees were invited. Ethical considerations in terms of the use of the measuring instruments, the analyses of the data and the manner in which the findings were conveyed were discussed with the test publishers.

\section{Statistical analysis}

All statistical analyses were based on the assumption that the sample $(N=118)$ was drawn from a normally distributed population. This was a reasonable assumption, given that a sample size of 25 or 30 is generally considered sufficiently large for most situations (Howell, 2002).

The Pearson product-moment coefficient (StatSoft, 2002) was used to determine whether any linear relationships existed between the dimensions of employee motivation and scales of job satisfaction (hypothesis 1), the domains of corporate culture and the scales of job satisfaction (hypothesis 2) and the domains of corporate culture and the dimensions of employee motivation (hypothesis 3). Raw scores and two-way $p$-values were used, the latter providing more information given the exploratory nature of the study. These relationships were further explored in terms of the significant drivers of said relationships using canonicalcorrelation analysis. This procedure allows the analysis of the linear relationship between two multidimensional variables or the correlation between two sets of variables. The outcome variables (the set of dependent variables) can be compared to the impacting variables (the set of independent variables) simultaneously (Statsoft, 2002). A canonical correlation of 0,45 was regarded as the cut-off guideline for interpretation. Based on the identified drivers, the moderator effect of employee motivation (hypothesis 4) was determined by splitting the sample into groups that scored high and low in terms of this construct and exploring the relationship between corporate culture and job satisfaction for the high and low groups by means of correlations (Visser \& Coetzee, 2005). A median split was used as well as the top $25 \%$ and the bottom $25 \%$ scorers. 


\section{RESULTS}

The relationship between employee motivation and job satisfaction: Hypothesis 1

Table 2 shows significant positive correlations between the Energy and dynamism dimension of the MQ and all the scales of the WLQ and a significant correlation between the Extrinsic dimension and the Remuneration, benefits and personnel policy scale. The latter correlation was negative, contrary to what was expected.

Table 3 provides the overall model fit for the canonical correlation between the MQ (the independent set of variables) and the WLQ (the dependent set of variables). The first two canonical functions were significant but only the first had an adequately high correlation for further interpretation (explaining $27 \%$ of the variance).

From Table 4, it can be seen that the highest loading on the WLQ was for Remuneration, benefits and personnel policy, followed by Task characteristics and Organisational functioning, while the highest loading on the MQ was recorded for Energy and dynamism.

The relationship between corporate culture and job satisfaction: Hypothesis 2

Table 5 shows that, with the exception of the relationship between Performance and Social matters, all the CCQ Lite domains and WLQ scales correlated significantly and positively with one another.

Table 6 provides the overall model fit for the canonical correlation between the CCQ Lite domains (the independent set of variables) and the WLQ scales (the dependent set of variables). All the canonical functions were significant, with the correlation for the first and for the second function (explaining $66 \%$ and $26 \%$ of the variance respectively) meeting the criterion for interpretation.

From Table 7, it is evident that, for the first canonical function, the WLQ was defined mostly by Organisational functioning and Remuneration, benefits and personnel policy, with some

TABLE 3

Canonical correlation analysis for the MQ dimensions and the WLQ scales

\begin{tabular}{rrrrrr}
\hline $\begin{array}{l}\text { MEASURES OF OVERALL MODEL FIT FOR CANONICAL CORRELATION } \\
\text { ANALYSIS }\end{array}$ \\
\hline $\begin{array}{r}\text { Canonical } \\
\text { function }\end{array}$ & $\begin{array}{l}\text { Canonical } \\
\text { correlation }\end{array}$ & $\begin{array}{l}\text { Canonical } \\
\boldsymbol{R}^{2}\end{array}$ & $\begin{array}{l}\text { Chi- } \\
\text { square }\end{array}$ & $\boldsymbol{d}$ 的 & Probability \\
\hline 1 & 0,525 & 0,275 & 62,641 & 24 & 0,000 \\
2 & 0,404 & 0,163 & 26,666 & 15 & 0,031 \\
3 & 0,233 & 0,054 & 6,764 & 8 & 0,562 \\
4 & 0,068 & 0,004 & 0,520 & 3 & 0,912 \\
\hline
\end{tabular}

TABLE 4
onical function between the MQ dimensions and

Canonical structure for the first canonical function between the MQ dimensions and
the WLQ scales

\section{CORRELATIONS BETWEEN THE DEPENDENT VARIABLES: WLQ}

SCALES AND THEIR CANONICAL VARIATE

\begin{tabular}{ll} 
Organisational functioning & 0,725 \\
Task characteristics & 0,804 \\
Physical working conditions & 0,499 \\
Career matters & 0,525 \\
Social matters & 0,570 \\
Remuneration, benefits and policy & 0,917 \\
CORRELATIONS BETWEEN THE INDEPENDENT VARIABLES: MQ & \\
DIMENSIONS AND THEIR CANONICAL VARIATE & \\
\hline Energy and dynamism & 0,922 \\
Synergy & $-0,148$ \\
Intrinsic & $-0,051$ \\
Extrinsic & $-0,226$ \\
\hline
\end{tabular}

TABLE 5

Pearson correlations between the domains of the CCQ and the scales of the WLQ

\begin{tabular}{|c|c|c|c|c|}
\hline & PERFORMANCE & $\begin{array}{l}\text { HUMAN } \\
\text { RESOURCES }\end{array}$ & $\begin{array}{l}\text { DECISION- } \\
\text { MAKING }\end{array}$ & RELATIONSHIPS \\
\hline \multicolumn{5}{|c|}{ Organisational functioning } \\
\hline correlation & 0,280 & 0,710 & 0,560 & 0,610 \\
\hline$p$-value & 0,002 & 0,000 & 0,000 & 0,000 \\
\hline \multicolumn{5}{|c|}{ Task characteristics } \\
\hline correlation & 0,210 & 0,470 & 0,480 & 0,540 \\
\hline$p$-value & 0,020 & 0,000 & 0,000 & 0,000 \\
\hline \multicolumn{5}{|c|}{ Physical working conditions } \\
\hline correlation & 0,420 & 0,370 & 0,390 & 0,450 \\
\hline$p$-value & 0,000 & 0,000 & 0,000 & 0,000 \\
\hline \multicolumn{5}{|c|}{ Career matters } \\
\hline correlation & 0,350 & 0,630 & 0,420 & 0,350 \\
\hline$p$-value & 0,000 & 0,000 & 0,000 & 0,000 \\
\hline \multicolumn{5}{|c|}{ Social matters } \\
\hline correlation & 0,170 & 0,440 & 0,290 & 0,480 \\
\hline$p$-value & 0,068 & 0,000 & 0,002 & 0,000 \\
\hline \multicolumn{5}{|c|}{ Remuneration, benefits, policy } \\
\hline correlation & 0,270 & 0,700 & 0,570 & 0,430 \\
\hline$p$-value & 0,003 & 0,000 & 0,000 & 0,000 \\
\hline
\end{tabular}

TABLE 6

Canonical correlation analysis for the CCQ domains and the WLQ scales

\begin{tabular}{|c|c|c|c|c|c|}
\hline \multicolumn{6}{|c|}{$\begin{array}{l}\text { MEASURES OF OVERALL MODEL FIT FOR CANONICAL CORRELATION } \\
\text { ANALYSIS }\end{array}$} \\
\hline $\begin{array}{l}\text { Canonical } \\
\text { function }\end{array}$ & $\begin{array}{l}\text { Canonical } \\
\text { correlation }\end{array}$ & $\begin{array}{l}\text { Canonical } \\
R^{2}\end{array}$ & $\begin{array}{l}\text { Chi- } \\
\text { square }\end{array}$ & $d f$ & Probability \\
\hline 1 & 0,811 & 0,657 & 180,136 & 24 & 0,000 \\
\hline 2 & 0,512 & 0,263 & 60,690 & 15 & 0,000 \\
\hline 3 & 0,385 & 0,148 & 26,731 & 8 & 0,001 \\
\hline
\end{tabular}

contribution by Career matters, while the Human resources domain followed by the Decision-making domain, had the highest loadings in the case of the CCQ Lite.

Table 8 shows the highest loading for the second function as Physical working conditions in the case of the WLQ and the Decision-making domain for the CCQ Lite. However, this relationship was negative, which indicated that the higher the Decision-making domain score became, the smaller the Physical working conditions score became.

The relationship between corporate culture and employee motivation: Hypothesis 3

Table 9 shows that Energy and dynamism was the only dimension of the MQ that correlated significantly with the CCQ Lite domains.

Table 10 provides the overall model fit for the canonical correlation between the CCQ Lite domains (the independent set of variables) and the MQ dimensions (the dependent set of variables) and shows that only the first canonical function (explaining $22 \%$ of the variance) was statistically significant.

Table 11 shows that the Energy and dynamism dimension loaded sizeably in the case of the MQ and the Relationships domain, followed by the Human resources domain and the Decision-making domain in the case of the CCQ Lite.

A three-way relationship among corporate culture, employee motivation and job satisfaction: Hypothesis 4

The Energy and dynamism dimension was identified as a significant driver in the relationships of employee motivation with job satisfaction as well as with corporate culture. High and low groups in terms of this dimension were formed and 
the correlations between the identified drivers for corporate culture (Human resources, Relationships and Decisionmaking) and job satisfaction (Organisational functioning, Task characteristics, Career matters and Remuneration, benefits and personnel policy) are presented in Table 12 .

A pattern was noted in that the correlations were numerically higher for the high groups in the case of Human resources for the Organisational functioning and Remuneration, benefits and personnel policy scales and in the case of all three corporate culture domains for the Career matters scale. The opposite was true for all other correlations. However, the differences in the magnitudes of the correlations were, in most instances, not pronounced and the correlations were statistically significant (with six exceptions) and represented mostly medium to large effect sizes regardless of motivation category.

\section{DISCUSSION}

The correlations among the three measuring instruments highlight three significant sets of relationships, namely between the WLQ and the Energy and dynamism dimension of the MQ, between the WLO and all domains of the CCQ Lite and between the CCQ Lite and the Energy and dynamism dimension of the $M Q$. The canonical correlations serve as reinforcement of the correlational results and provide auxiliary information on the most significant contributors in the relationships among the $M Q$, WLQ and CCQ Lite. Certain aspects of employee motivation, job satisfaction and corporate culture contributed more powerfully towards the relationships than others. However, support for the moderator effect of employee motivation that was expected to provide the basis for a three-way relationship was not found.

TABLE 7

Canonical structure for the first canonical function between the CCQ lite domains and the WLQ scales

CORRELATIONS BETWEEN THE DEPENDENT VARIABLES:

WLQ SCALES AND THEIR CANONICAL VARIATE

\begin{tabular}{ll}
\hline Organisational functioning & 0,905 \\
Task characteristics & 0,642 \\
Physical working conditions & 0,511 \\
Career matters & 0,771 \\
Social matters & 0,536 \\
Remuneration, benefits and policy & 0,890 \\
CORRELATIONS BETWEEN THE INDEPENDENT VARIABLES: & \\
CCQ LITE DOMAINS AND THEIR CANONICAL VARIATE & \\
\hline Performance & 0,434 \\
Human resources & 0,966 \\
Relationships & 0,684 \\
Decision-making & 0,779 \\
\hline
\end{tabular}

TABLE 8

Canonical structure for the second canonical function between the CCQ lite domains and the WLQ scales

CORRELATIONS BETWEEN THE DEPENDENT VARIABLES:

WLQ SCALES AND THEIR CANONICAL VARIATE

\begin{tabular}{lc}
\hline Organisational functioning & $-0,178$ \\
Task characteristics & $-0,046$ \\
Physical working conditions & 0,662 \\
Career matters & 0,195 \\
Social matters & $-0,191$ \\
Remuneration, benefits and policy & $-0,092$ \\
CORRELATIONS BETWEEN THE INDEPENDENT VARIABLES: & \\
CCQ LITE DOMAINS AND THEIR CANONICAL VARIATE & \\
\hline Performance & $-0,071$ \\
Human resources & 0,069 \\
Relationships & $-0,149$ \\
Decision-making & $-0,724$ \\
\hline
\end{tabular}

The relationship between employee motivation and job satisfaction: Hypothesis 1

The Energy and dynamism dimension of employee motivation refers to the extent to which employees are motivated by a considerable workload and stimulating work content, by the need to achieve success, avoid failure and exercise authority in a competitive work environment and by a workplace demanding due emphasis on commercial growth and development. The needs and motives associated with this dimension were significantly and positively related to all aspects of job satisfaction, in particular to job characteristics, matters involving remuneration and benefit structures, and organisational functioning.

Previous research has shown that job satisfaction is affected by the extent to which employees perceive their work as challenging and stimulating (Coster, 1992; Du Plessis, 2003; Maslow, 1968; Rothmann \& Coetzer, 2002; Stinson \& Johnson, 1977; Vercueil, 1970; Visser et al., 1997) as well as meaningful (Hackman \& Oldham, 1976; Porter, Lawler \& Hackman, 1975; Tyagi, 1985). Goal orientation has also been shown to be positively related to job satisfaction (Bellenger et al., 1984; Coster, 1992; Spector, 2003 Strydom \& Meyer, 2002), as has the need for power (Becherer et al., 1982; Coster, 1992; Hoole \& Vermeulen, 2003).

The negative correlation between the Extrinsic dimension and the Remuneration, benefits and personnel policy scale is not supported by literature (e.g. Agho et al., 1993; Bellenger et al., 1984; Hoole \& Vermeulen, 2003). The hypothesised relationships of the Synergy and the Intrinsic dimensions of motivation with job satisfaction did not realise, either. A possible interpretation is that the marketing research environment is characterised by factors that drive employees motivated by Energy and dynamism but that this environment does not support factors that lead to job satisfaction for those motivated by, for example, affiliation, recognition, flexibility and especially material and other external forms of reward.

The relationship between corporate culture and job satisfaction: Hypothesis 2

Employees' perceptions of the organisational culture related directly to their level of job satisfaction. Positive perceptions of the human-resources orientation in particular were important,

TABLE 9
Pearson correlations between the dimensions of the MQ and the domains of the

\begin{tabular}{lcccc}
\hline & $\begin{array}{l}\text { ENERGY } \\
\text { AND } \\
\text { DYNAMISM }\end{array}$ & SYNERGY & INTRINSIC & EXTRINSIC \\
\hline Performance & & & & \\
\hline correlation & 0,220 & 0,050 & $-0,020$ & 0,160 \\
$\begin{array}{l}p \text {-value } \\
\text { Human resources }\end{array}$ & 0,014 & 0,550 & 0,868 & 0,083 \\
\hline correlation & 0,360 & $-0,060$ & $-0,080$ & $-0,100$ \\
$\begin{array}{l}p \text {-value } \\
\text { Decision-making }\end{array}$ & 0,000 & 0,501 & 0,382 & 0,292 \\
\hline correlation & 0,390 & $-0,080$ & $-0,140$ & $-0,050$ \\
$\quad p$-value & 0,000 & 0,371 & 0,120 & 0,628 \\
Relationships & & & & \\
\hline correlation & 0,390 & 0,070 & 0,030 & 0,080 \\
$p$-value & 0,000 & 0,484 & 0,708 & 0,418 \\
\hline
\end{tabular}

TABLE 10

Canonical correlation analysis for the CCQ lite domains and the MQ dimensions

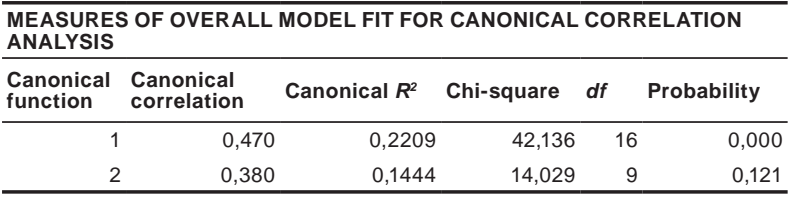


TABLE 11

Canonical structure for the first canonical function between the CCQ lite domains and the MQ dimensions

\section{CORRELATIONS BETWEEN THE DEPENDENT VARIABLES}

MQ DIMENSIONS AND THEIR CANONICAL VARIATE

\begin{tabular}{lr}
\hline Energy and dynamism & $-0,923$ \\
Synergy & 0,134 \\
Intrinsic & 0,230
\end{tabular}

Intrinsic

0,125

CORRELATIONS BETWEEN THE INDEPENDENT VARIABLES:

CCQ LITE DOMAINS AND THEIR CANONICAL VARIATE

\begin{tabular}{ll}
\hline Performance & $-0,406$ \\
Human resources & $-0,861$ \\
Relationships & $-0,906$ \\
Decision-making & $-0,769$ \\
\hline
\end{tabular}

TABLE 12

Correlations between drivers for corporate culture and job satisfaction for high and low groups on energy and dynamism

\begin{tabular}{|c|c|c|c|c|}
\hline & ORGANISATION & TASK & CAREER & REMUNERATION \\
\hline \multicolumn{5}{|l|}{ Human resources } \\
\hline median low $(n=59)$ & $0,652^{\star \star}$ & $0,456^{\star *}$ & $0,513^{\star \star}$ & $0,589^{\star *}$ \\
\hline median high $(n=59)$ & $0,738^{\star \star}$ & $0,381^{\star \star}$ & $0,711^{* *}$ & $0,728^{\star *}$ \\
\hline low 25\% $(n=29)$ & $0,651^{\star \star}$ & $0,606^{\star \star}$ & $0,459^{*}$ & $0,597^{\star *}$ \\
\hline high 25\% ( $n=29)$ & $0,749^{\star \star}$ & $0,561^{\star \star}$ & $0,802^{\star \star}$ & $0,832^{\star \star}$ \\
\hline \multicolumn{5}{|l|}{ Relationships } \\
\hline median low $(n=59)$ & $0,593^{\star \star}$ & $0,514^{\star \star}$ & $0,296^{*}$ & $0,355^{\star \star}$ \\
\hline median high $(n=59)$ & $0,522^{\star \star}$ & $0,440^{* *}$ & $0,364^{\star *}$ & $0,360^{\star *}$ \\
\hline low $25 \%(n=29)$ & $0,714^{\star \star}$ & $0,593^{\star \star}$ & 0,184 & $0,402^{*}$ \\
\hline high $25 \%(n=29)$ & 0,355 & $0,429^{\star}$ & $0,368^{*}$ & 0,325 \\
\hline \multicolumn{5}{|l|}{ Decision-making } \\
\hline median low $(n=59)$ & $0,565^{\star \star}$ & $0,476^{* *}$ & $0,371^{\star \star}$ & $0,457^{\text {** }}$ \\
\hline median high $(n=59)$ & $0,414^{\star \star}$ & 0,252 & $0,334^{\star \star}$ & $0,383^{\star \star}$ \\
\hline low $25 \%(n=29)$ & $0,566^{* *}$ & $0,535^{\star *}$ & 0,242 & $0,553^{\star \star}$ \\
\hline high $25 \%(n=29)$ & 0,298 & $0,460^{\star}$ & $0,385^{\star}$ & $0,381^{*}$ \\
\hline
\end{tabular}

* $p \leq 0,05$

$* * p \leq 0,01$

followed by perceptions of the decision-making culture, relationships in the organisation and, lastly, performance orientation. The major drivers in the case of job satisfaction were organisational functioning, feelings about remuneration and benefits, and career matters.

A perceived concern for employees has been highlighted in numerous previous investigations (Agho et al., 1993; Odom et al., 1990; Putti \& Kheun, 1986; Ritter \& Anker, 2002; Van Vuuren, $1990)$, as is the case with access to equal opportunities (Coetzee \& Vermeulen, 2003; Ritter \& Anker, 2002; Veeran \& Katz, 2002; Visser et al., 1997). Job satisfaction has also been shown to be negatively related to a bureaucratic culture (Du Preez, 2003; Goodman et al., 2001; Lok \& Crawford, 2001; Odom et al., 1990); it has been shown to be positively related to the extent to which employees are involved in day-to-day decision making (Churchill et al., 1976; Cohen-Rosenthal \& Cairnes, 1991; Du Preez, 2003; Elizur, 1990; Gunter \& Furnham, 1996; Johnson \& McIntye, 1998; Maree, 2000; McNeely, 1983; Mohrman, Lawler \& Ledford, 1996; Packard, 1989; Valoyi, Lessing \& Schepers, 2000; Visser et al., 1997). Poor relationships in the work environment are generally believed to undermine job satisfaction (Agho et al., 1993; Cohen-Rosenthal \& Cairnes, 1991; Du Preez, 2003; Gunter \& Furnham, 1996; McNeely, 1983; Ritter \& Anker, 2002; Strydom \& Meyer, 2002; Visser et al., 1977). The positive relationship of satisfaction with the enforcement of quality and the encouragement of creativity are also supported (CohenRosenthal \& Cairnes, 1991; Coster, 1992; Johnson \& McIntye, 1998; Odom et al., 1990; Putti \& Kheun, 1986).

The positive relationship with excessive pressure in terms of workload has been unexpected (Agho et al., 1993; Becherer et al., 1982; Bhargava \& Kelkar, 2000). This relationship could be due to the fact that a consistent, heavy workload is inherent in the marketing research environment and therefore not unusual. The finding associated with the second function, namely that greater job satisfaction in terms of physical working conditions is associated with the perception that an organisation emphasises performance to a lesser degree is hard to explain and, in fact, contradictory to findings from the first function.

The relationship between corporate culture and employee motivation: Hypothesis 3

Employees' perceptions of, in particular, a company's relationships and human-resources culture as well as the decision-making and, to a lesser extent, performance orientation also related to the needs and motives associated with the Energy and dynamism dimension. A relationship between corporate culture and motivation was hypothesised based on the relationship of both these constructs with job satisfaction. In this study, only the Energy and dynamism dimension of motivation was found to be related to job satisfaction, which, in turn, was related to corporate culture (with satisfaction in terms of organisational functioning and remuneration and benefits featuring strongly in both relationships). The relationship found between corporate culture and this dimension of motivation follows from this.

Although no specific reference is made in literature to a direct relationship between these constructs, an inferred relationship is supported. For example, the positive impact of aspects of the Energy and dynamism dimension, such as challenging and stimulating (e.g. Coster, 1992; Du Plessis, 2003) as well as meaningful work (e.g. Hackman \& Oldham, 1976; Porter et al., 1975), on job satisfaction is reflected in the positive relationship of a corporate culture characterised by the enforcement of quality and the encouragement of creativity with satisfaction (Cohen-Rosenthal \& Cairnes, 1991; Coster, 1992; Johnson \& McIntye, 1998; Odom et al., 1990; Putti \& Kheun, 1986).

A three-way relationship among corporate culture, employee motivation and job satisfaction: Hypothesis 4

The moderator effect of employee motivation for the relationship between corporate culture and job satisfaction was not supported by the results of this study. Specifically, the effect of the Energy and dynamism dimension of motivation was investigated. The significance of this dimension in the linear relationships was interpreted in terms of its relevance to the marketing research environment. However, focus on this aspect in the exploration of a possible multivariate relationship limited the definition of "motivation". The theoretical similarities between employee motivation and job satisfaction could also have confounded the results. Moynihan and Pandey (2007) argue for a more abstract notion of "motivation" that overlaps with attitudes such as job satisfaction, organisational commitment and job involvement. Given the reduced sample sizes for the sample splits, the overinterpretation of the patterns that were observed should be avoided.

\section{CONCLUSIONS}

The relationships found between employee motivation and job satisfaction, corporate culture and job satisfaction, and corporate culture and employee motivation correspond with what is reported in literature. In this regard, Moynihan and Pandey (2007) comment on the difficulty of adding anything new in terms of independent-dependent variable relationships in the study of workplace attitudes. However, the identification of significant drivers of these relationships provides organisations (especially in the marketing research context) with information that can be used to increase employee motivation and job satisfaction, which ultimately determine organisational performance. 
The relationships were largely shaped by energy and dynamism as a motivational construct, by perceptions of task characteristics, organisational functioning, and remuneration and benefit structures in terms of how these variables relate to job satisfaction and by the organisation's human-resources, decision-making and relationships culture. The role played by the Energy and dynamism dimension of employee motivation in the marketing research environment has implications for the selection of personnel. Furthermore, the study not only identifies the drivers of the relationships but also contributes by reflecting on the relative degree of managerial influence over workplace attitudes (De Witte, 2005; Egan, Yang \& Bartlett, 2004; Moynihan \& Pandey, 2007). Most of the identified drivers are those that are directly under the influence of an organisation.

Theoretically, this study has found meaningful results. A larger sample and the complex multivariate analyses made possible by such an increase may have contributed more in terms of a three-way relationship, although feasible explanations other than the sample size are provided for the tentative findings in terms of such a relationship. The nature of the study and the composition of the sample furthermore contribute to ecological validity. Future research to increase the generalisability of the results should avoid a mere increase in sample size and rather consider design options that can be used as part of a metaanalysis.

\section{ACKNOWLEDGEMENTS}

We would like to thank SHL (in particular Tina Joubert) and RAU Statcon (now the University of Johannesburg) for support with this study. Our thanks also go to the host organisation for participating in the study.

\section{REFERENCES}

Adams, J.S. (1965). Inequity in social exchange. In L. Berkowitz (ed.). Advances in experimental social psychology, Vol. 2 (pp. 267-299). New York: Academic Press.

Agho, A.O., Mueller, C.W. \& Price, J.L. (1993). Determinants of employee job satisfaction: An empirical test of a causal model. Human Relations, 46(8):1007-1027.

Alvesson, M. (2002). Understanding organizational culture. London: Sage Publications.

Arnold, H.J. \& Feldman, D.C. (1986). Organizational behavior. New York: McGraw-Hill.

Bard, M. \& Moore, E. (2000). Mentoring and self-managed learning: Professional development for the market research industry. International Journal of Market Research, 42(3):255-265

Baron, H., Henley, S., McGibbon, A. \& McCarthy, T. (2002). Motivation questionnaire manual and user's guide. Sussex: Saville and Holdsworth Limited.

Beach, D.S. (1980). Personnel: The management of people at work (4th ed.). New York: Macmillan Publishing Co. Inc.

Becherer, R.C., Morgan, F.W. \& Richard, L.M. (1982). The job characteristics of industrial salespersons: Relationship to motivation and satisfaction. Journal of Marketing, 46(4):125-135

Beck, R.C. (1983). Motivation: Theories and principles (2nd ed.). New Jersey: Prentice Hall.

Bellenger, D.N., Wilcox, J.B. \& Ingram, T.N. (1984). An examination of reward preferences for sales managers. Journal of Personal Selling and Sales Management, 4(2):1-6.

Bhargava, S. \& Kelkar, A. (2000). Prediction of job involvement, job satisfaction, and empowerment from organizational structure and corporate culture. Psychological Studies, 45(1-2):43-50.

Campbell, J.P. \& Pritchard, R.D. (1976). Motivation theory in industrial and organizational psychology. In M.D. Dunnette (ed.). Handbook of industrial and organizational psychology (pp. 63-130). Chicago: Rand McNally.
Churchill, G.A., Ford, N.M. \& Walker,O.C. (1976). Organizational climate and job satisfaction in the salesforce. Journal of Marketing Research, 13(4):323-332.

Coetzee, M. \& Vermeulen, L. (2003). How should organisations handle employee injustices? Management Today, 19(8):28-32.

Cohen-Rosenthal, E. \& Cairnes, L. (1991). Doing the best job. Journal for Quality and Participation, 14(3):48-53.

Cooper, C.L., Cartwright, S. \& Earley, P.C. (2001). Introduction. In C.L. Cooper, S. Cartwright \& P.C. Earley (eds.). The international handbook of organizational culture and climate (pp. xv-xix). Chichester: John Wiley \& Sons, Ltd.

Coster, E.A. (1992). The perceived quality of working life and job facet satisfaction. Journal of Industrial Psychology, 18(2):6-9.

Davies, B., Phil, A. \& Warr, P. (2000). Corporate Culture Questionnaire manual and user's guide. Sussex: Saville and Holdsworth Limited.

Davy, J.A., Kinicki, A.J. \& Scheck, C.L. (1997). A test of job security's direct and mediated effects on withdrawal cognitions. Journal of Organizational Behavior, 18:323-349.

De Cuyper, N. \& De Witte, H. (2005). Job insecurity: Mediator or moderator of the relationship between type of contract and various outcomes? South African Journal of Industrial Psychology, 31(4):79-86.

Deshpande, S.P. (1996). The impact of ethical climate types on facets of job satisfaction: An empirical investigation. Journal of Business Ethics, 15:655-660.

De Witte, H. (2005). Long-term job insecurity, job satisfaction and organisational attitudes: Test of Warr's curvilinear hypothesis. South African Journal of Industrial Psychology, 31(4):41-47.

Du Plessis, S. (2003). Purpose is alive and well and living inside you: Key feature. Career Success, 3(1):1-2.

Du Preez, D. (2003). Insights into organisational challenges. People Dynamics, 21(9):28-30.

Du Toit, M.A. (1990). Motivering (Motivation). In J. Kroon (ed.). Algemene bestuur (General management) (2nd ed.). (pp. 83-92). Pretoria: HAUM.

Egan, T.M., Yang, B. \& Bartlett, K.R. (2004). The effects of organizational learning culture and job satisfaction on motivation to transfer learning and turnover intention. Human Resource Development Quarterly, 15(3):279-301.

Elizur, D. (1990). Quality circles and quality of work life. International Journal of Manpower, 11(6):3-8.

Finck, G., Timmers, J. \& Mennes, M. (1998). Satisfaction vs. motivation. Across the Board, 35(9):55-56.

Fried, Y. \& Ferris, G.R. (1987). The validity of the job characteristics model: A review and meta-analysis. Personnel Psychology, 40:287-322.

Goodman, E.A., Zammuto, R.F. \& Gifford, B.D. (2001) Understanding the impact of organizational culture on the quality of work life. Organization Development Journal, 19(3):58-68.

Gouws, A. (1995). Die verwantskap tussen motivering en werkstevredenheid van 'n groep inligtingspesialiste (The relationship between motivation and job satisfaction of a group of information specialists). Unpublished M.Bib. dissertation. Rand Afrikaans University.

Gunter, B. \& Furnham, A. (1996). Biographical and climate predictors of job satisfaction and pride in organizations. Journal of Psychology, 130(2):193-208.

Guppy, A. \& Rick, J. (1996). The influence of sex and grade on perceived work stress and job satisfaction in white collar employees. Work and Stress, 10(2):154-164.

Hackman, J.R. \& Oldham, G.R. (1976). Motivation through the design of work: Test of a theory. Organizational Behavior and Human Performance, 16(2):250-279.

Hoole, C. \& Vermeulen, L.P. (2003). Job satisfaction among South African pilots. South African Journal of Industrial Psychology, 29(1):52-57.

Howell, D.C. (2002). Statistical methods for psychology (5th ed.). USA: Duxbury.

Huysamen, G.K.(1996). Psychological measurement: An introduction with South African examples (3rd ed.). Pretoria: Van Schaik. 
Jernigan, I.E., Beggs, J.M. \& Kohut, G.F. (2002). Dimensions of work satisfaction as predictors of commitment type. Journal of Managerial Psychology, 17(7):564-579.

Johnson, J.J. \& McIntye, C.L. (1998). Organizational culture and climate correlates of job satisfaction. Psychological Reports, 82:843-850.

Judge, T.A. \& Watanabe, S. (1993). Another look at the job satisfaction-life satisfaction relationship. Journal of Applied Psychology, 78:939-948.

Kemp, N.J., Wall, T.D., Clegg, C.W. \& Cordery, J.L. (1983). Autonomous work groups in a greenfield site: A comparative study. Journal of Occupational Psychology, 56(4):271-288.

Lok, P. \& Crawford, J. (2001). Antecedents of organizational commitment and the mediating role of job satisfaction. Journal of Managerial Psychology, 16(8):594-613.

Maree, J. (2000). Worker participation in decision-making: Who benefits? Society in Transition, 31(2):111-125.

Maslow, A.H. (1968). Toward a psychology of being. New York: Van Nostrand Reinhold Company.

McClelland, D.C. (1987). Human motivation. Cambridge: Cambridge University Press.

McCormick, E.J. \& Ilgen, D.R. (1980). Industrial psychology (7th ed.). Englewood Cliffs, NJ: Prentice Hall.

McNeely, R.L. (1983). Organizational patterns and work satisfaction in a comprehensive human service agency: An empirical test. Human Relations, 36(10):957-972.

Mohrman, S.A., Lawler, E.E. \& Ledford, G.E. (1996). Do employee involvement and TQM programs work? Journal for Quality and Participation, 19(1):6-11.

Mol, A. (1990). Help! Ek is 'n bestuurder (Help! I am a manager). Cape Town: Tafelberg Publishers.

Moon, M.J. (2000). Organizational commitment revisited in new public management. Public Performance and Management Review, 24(2):177-194.

Moynihan, D.P. \& Pandey, S.K. (2007). Finding workable levers over work motivation: Comparing job satisfaction, job involvement, and organizational commitment. Administration E Society, 39(7):803-832.

Odom, R.Y., Boxx, W.R. \& Dunn, M. (1990). Organizational cultures, commitment, satisfaction and cohesion. Public Productivity and Management Review, 14(2):157-169.

Orpen, C. (1994). Interactive effects of work motivation and personal control on employee job performance and satisfaction. Journal of Social Psychology, 134(6):855-856.

Ott, J.S. (1989). The organizational culture perspective. California: Brooks/Cole Publishing Company.

Packard, T. (1989). Participation in decision-making, performance, and job satisfaction in a social work bureaucracy. Administration in Social Work, 13(1):59-74.

Perry, J.L. \& Porter, L.W. (1982). Factors affecting the context for motivation in public organizations. Academy of Management Review, 7(1):89-98.

Peters, T.J. \& Waterman, R.H. (1982). In search of excellence. New York: Warner Books.

Pinder, C.C. (1998). Work motivation in organizational behaviour. Upper Saddle River, NJ: Prentice-Hall.

Porter, L.W., Lawler, E.E. \& Hackman, J.R. (1975). Behavior in organizations. New York: McGraw-Hill.

Putti, J.M. \& Kheun, L.S. (1986). Organizational climate-job satisfaction relationship in a public sector organization. International Journal of Public Administration, 8(3):337-344.

Ritter, J.A. \& Anker, R. (2002). Good jobs, bad jobs: Workers' evaluations in five countries. International Labour Review, 141(4):331-358.

Rothmann, S. \& Coetzer, E.P. (2002). The relationship between personality dimensions and job satisfaction. Bestuursdinamika, 11(1):29-42.

Schein, E.H. (1984). Coming to a new awareness of organizational culture. Sloans Management Review, Winter, 3-16.

Schein, E.H. (1985). Organizational culture and leadership. San Francisco: Jossey-Bass Publishers.
Schofield, P. (1998). It's true: Happy workers are more productive. Works Management, 51(12):33-35.

Schultz, D. \& Schultz, S.E. (1998). Psychology and work today: An introduction to industrial and organizational psychology (7th ed.). New Jersey: Prentice Hall.

Sempane, M.E., Rieger, H.S. \& Roodt, G. (2002). Job satisfaction in relation to organisational culture. South African Journal of Industrial Psychology, 28(2):23-30.

Shepard, J.M. (1973). Specialization, autonomy, and job satisfaction. Industrial Relations, 12(3):274-281.

Spector, P.E. (2003). Industrial and organizational psychology: Research and practice (3rd ed.). New York: John Wiley \& Sons, Inc.

StatSoft, Inc. (2002). Electronic statistics textbook. Tulsa, OK.

Stinson, J.E. \& Johnson, T.W. (1977). Tasks, individual differences, and job satisfaction. Industrial Relations, 16(3):315-325.

Strydom, S.C. \& Meyer, J.C. (2002). 'n Ondersoek na die bronne van werkstevredenheid en werkstres onder middelvlakbestuurders in die Wes-Kaap (An investigation of the sources of job satisfaction and work stress among middle-level managers in the Western Cape). South African Journal of Industrial Psychology, 28(2):15-22.

Thomson, D. (2003). Incentive schemes have to work! Management Today, 18(10):46-47.

Tyagi, P.K. (1985). Work motivation through the design of salesperson jobs. Journal of Personal Selling and Sales Management, 5(1):41-52.

Valoyi, E.G., Lessing, B.C. \& Schepers, J.M. (2000). Participation in decision-making. South African Journal of Industrial Psychology, 26(3):15-21.

Van Vuuren, S.M. (1990). Die verband tussen sekere persoonlikheidseienskappe en werkstevredenheid by die predikant (The relationship between certain personality characteristics and job satisfaction in the clergyman). Unpublished D. thesis. Rand Afrikaans University.

Van Zyl, E.S. \& Van der Walt, H.S. (1991). Manual for Experience of Work and Life Circumstances Questionnaire. Pretoria: HSRC.

Veeran, P. \& Katz, L. (2002). An exploratory study of the relationship between interpersonal justice perceptions and job satisfaction in an organisation undergoing change. South African Journal of Labour Relations, 26(2):4-24.

Vercueil, J.C. (1970). Die verband tussen sekere persoonlikheidseienskappe, werkstevredenheid en personeelomset in ' $n$ hoogs gespesialiseerde industriële onderneming (The relationship between certain personality characteristics, job satisfaction and personnel turnover in a highly specialised industrial organisation). Unpublished M.A. dissertation. Rand Afrikaans University.

Visser, D. \& Coetzee, S. (2005). Affective-cognitive consistency of attitude as a moderator of the job satisfaction-performance relationship. South African Journal of Industrial Psychology, 31(3):62-69.

Visser, P.J., Breed, M. \& Van Breda, R. (1997). Employee satisfaction: A triangular approach. Journal of Industrial Psychology, 23(2):19-24.

Viswesvaran, C. \& Deshpande, S.P. (1996). Ethics, success and job satisfaction: A test of dissonance theory in India. Journal of Business Ethics, 15(10):1065-1069.

Vroom, V.H. (1964). Work and motivation. New York: John Wiley.

Walker, J.W. (1980). Human resource planning. New York: McGrawHill Book Company.

Watson, T. (1994). Linking employee motivation and satisfaction to the bottom line. CMA Magazine, 68(3):4.

Weaver, C.N. (1988). Relationships among pay, race, sex, occupational prestige, supervision, work autonomy, and job satisfaction in a national sample. Personnel Psychology, 30(3):437-445.

Weeks, R.V. \& Lessing, N. (1988). Organizational culture: The missing link within the strategic management process. Rand Afrikaans University. 